\title{
Copper II - polar amino acid complexes: toxicity to bacteria and larvae of Aedes aegypti
}

\author{
THIAGO A.D. RODRIGUES ${ }^{1}$, EDUARDO J. DE ARRUDA ${ }^{1}$, MAGDA F. FERNANDES ${ }^{1,4}$, \\ CLAUDIO T. DE CARVALHO ${ }^{1}$, ALESSANDRA R. LIMA ${ }^{2}$ and ISAÍAS CABRINI ${ }^{1,3}$

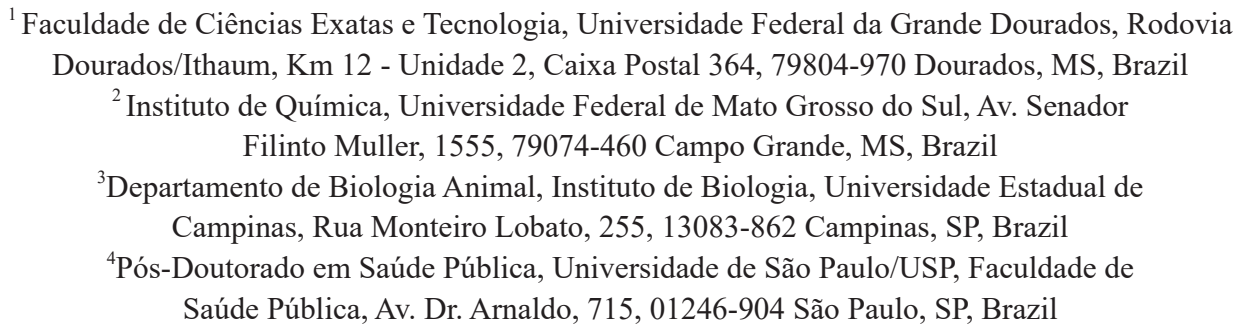

Manuscript received on November 21, 2016; accepted for publication on March 8, 2017

\begin{abstract}
Control strategies using insecticides are sometimes ineffective due to the resistance of the insect vectors.In this scenario new products must be proposed for the control of insect vectors. The complexes L-aspartate $\mathrm{Cu}$ (II) and L-glutamate- $\mathrm{Cu}$ (II) complexes were synthesized and characterized by elemental analysis, visible ultraviolet, infrared spectroscopy and potentiometric titration. The toxicity of these complexes was analyzed in Aedes aegypti (Diptera: Culicidae) larvae and Gram-negative and Gram-positive bacteria. The interaction between the ligands and the amino acid balance and the distribution of the species as a function of $\mathrm{pH}$ were discussed. The lethal concentration median $\left(\mathrm{LC}_{50}\right)$ for Ae. aegypti larvae were: L-glutamic acid$\mathrm{Cu}$ (II) - $53.401 \mathrm{mg} \mathrm{L}^{-1}$ and L-aspartate-Cu (II) - $108.647 \mathrm{mg} \mathrm{L}^{-1}$. The minimum inhibitory concentration (MIC) required for Staphylococcus aureus and Escherichia coli was: L-glutamate-Cu (II) 500-2000 mg $\mathrm{L}^{-1}$ and L-aspartate-Cu (II) $1000-2000 \mathrm{mg} \mathrm{L}^{-1}$. The concentrations demonstrated toxicity that evidence the potential of the complexes as bactericide and insecticide. Metal complexes formed by amino acids and transition metals are advantageous because of low environmental toxicity, biodegradability and low production cost.
\end{abstract}

Key words: Neurotransmitter, bacteria, population control of vectors, metal-insecticide, mosquito.

\section{INTRODUCTION}

The control of insect vectors of neglected diseases (dengue, chikungunya, zika) has been hampered by the occurrence of insect resistant populations, the adaptability of insects to synthetic and biological

Correspondence to: Eduardo Jose de Arruda

E-mail: ejarruda@gmail.com insecticides and the absence of new and effective molecules with low environmental impact (Corbel et al. 2016).

The $\mathrm{Cu}$ (II) ion is a bioactive metal and essential micronutrientwith a narrow range of biological toxicity that, coordinated with ligands, is transported to the intracellular environment and causes in situ oxidative stress reactions with the 
production of free radicals and oxidant species (ROS), as well as disorganization of the peritrophic matrix and destruction of the intestinal microvilli of mosquito larvae (Arruda et al. 2010, Gopinathan and Arumugham 2014, Nardeli et al. 2014, Gaban et al. 2015). In addition, it is a powerful antimicrobial agent that if used as a contact surface for metal alloys, inactivates microorganisms such as Escherichia coli, Pseudomonas aeruginosa and Staphylococcus aureus (Neciosup et al. 2015).

The glutamic acid and aspartic acid are neurotransmitters and act on the central and peripheral nervous system of insects and may be metal binders. L-glutamate (excitatory) and $\gamma$-amino butyric acid (inhibitor) are neurotransmitters that control the permeability of chloride ions $\left(\mathrm{Cl}^{-}\right)$and the change in this interaction may lead to greater permeability to $\mathrm{Cl}^{-}$ ions, causing nervous hyperexcitation (Beyenbach 2012), which is metabolically important because it causes an increase in the metabolic activity of oxidative stress induced by the presence of transition metals. Thus, the control of immature stages of insects can be proposed by the action of metallic complexes in the digestive system and neuromuscular junction (glutaminergic action). Homeostasis is obtained by dissociation complexes with a balance of L-glutamate and $\gamma$-amino butyric acid and by changing the availability of chloride ions, $\mathrm{Cl}^{-}$. This change affects the permeability of chloride ion junction and may block or increase nerve stimulation (Schooley et al. 2012). These conditions are unfavorable for the insect and may be promoted by the redox activity of metal complexes for induction of oxidative stress or competition for metal between important metabolic species.

The objectives of this study were the synthesis and characterization of L-glutamate- $\mathrm{Cu}$ (II) and L-aspartate- $\mathrm{Cu}$ (II) complexes for evaluation of their biological activity in Ae. aegypti larvae and bactericidal activity in $S$. aureus (ATCC 25923) and E. coli (ATCC 25922) for the secondary control of the microbiota of insect breeding.

\section{MATERIALS AND METHODS}

SYNTHESIS OF COMPLEXES L-glutamate-Cu (II) AND L-aspartate- $\mathrm{Cu}$ (II)

Metal-amino acids were synthesized using methods available in the literature (Rayms-Keller et al. 1998, Baran et al. 2000, Brumano 2008). The studies for the two acidic $\alpha$-amino acids present in almost al1proteins, i.e., L-aspartic and L-glutamic acid. The L-glutamate-Cu (II) was synthesized by mixing aqueous solutions of L-glutamic acid 19.7 mmol (Sigma-Aldrich 99\%) and $19.7 \mathrm{mmol}$ of copper (II) nitrate (Vetec/Sigma-Aldrich 99\%) at $80^{\circ} \mathrm{C}$, by stirring for 1 hour, followed by allowing the solution to stand for 24 hours in absolute ethanol to precipitate the complex L-glutamate$\mathrm{Cu}$ (II). The precipitate was filtered using a filter paper, washed with absolute ethanol and then dried in vacuum desiccator for characterization. The same procedure was used for the synthesis of L-aspartate-Cu (II), $10.2 \mathrm{mmol}$ of L-aspartic acid (Sigma-Aldrich 99\%) and $10.2 \mathrm{mmol}$ of copper (II) nitrate (Vetec/Sigma Aldrich 99\%) at the same conditions, followed by precipitation, washing, and drying. The $\mathrm{Cu}$ (II) complexes were recrystallized.

The composition of both complexes was confirmed by elemental analysis.

CHARACTERIZATION OF THE METAL-AMINO ACID

The metal-amino acid complexes were analyzed in solid form by elemental analysis ( $\mathrm{CHN})$ and infrared spectroscopy (IR), and in solution by potentiometric titrations and UV-Vis spectroscopy. The IR analysis was performed using a spectrophotometer model JASCO FT/IR-4100, using KBr (Sigma-Aldrich $99 \%$ ) with a scan range of $400 \mathrm{~cm}^{-1}-4000 \mathrm{~cm}^{-1}$.

The potentiometric titrations were performed by combined $\mathrm{pH}$ electrode ( $\mathrm{pH}$ Instrutherme 2000) with data analysis by Microcal Origin 6.0 software. 
A standard solution of $\mathrm{NaOH}\left(0.300 \mathrm{~mol} \mathrm{~L}^{-1}\right)$ (Vetec/Sigma-Aldrich 99\%) was used as the titrant for L-aspartic acid $\left(0.0500 \mathrm{~mol} \mathrm{~L}^{-1}\right)$ (Vetec/SigmaAldrich 99\%), L-glutamic (0.0500 $\left.\mathrm{mol} \mathrm{L}^{-1}\right)$ (Vetec/ Sigma-Aldrich 99\%), L-aspartate-Cu (II) (0.0500 mol L $\left.{ }^{-1}\right)$, and L-glutamate-Cu (II) $\left(0.0500 \mathrm{~mol} \mathrm{~L}^{-1}\right)$.

The elemental analysis of L-glutamate-Cu (II) and L-aspartate-Cu (II) were performed on Perkin Elmer model 2400 analyzer (IQ/Campinas, Brazil).

EVALUATION OF INSECTICIDAL ACTIVITY WITH Aedes aegypti LARVAE

Toxicity bioassays for analyzing insecticidal activity of amino acids and metal complexes were performed. For the compound L-glutamate-Cu (II), concentrations used were $50 \mathrm{mg} \mathrm{L}^{-1}, 200 \mathrm{mg} \mathrm{L}^{-1}$, and $600 \mathrm{mg} \mathrm{L}^{-1}$, and for L-aspartate-Cu (II) 200 $\mathrm{mg} \mathrm{L}^{-1}, 500 \mathrm{mg} \mathrm{L}^{-1}$, and $1000 \mathrm{mg} \mathrm{L}^{-1}$. Plots of 20 $3^{\text {rd }}$ instar larvae of Ae. aegypti (Rockefeller strain) were used for each concentration in eight replicates, each in $20 \mathrm{~mL}$ solution. Mortality was observed after 24 hours of application. Distilled water was used as control, whereas amino acids glutamate and aspartate in aqueous solution (1000 $\left.\mathrm{mg} \mathrm{L}^{-1}\right)$, an organophosphate insecticide, Temephos ${ }^{\circledR}(1 \mathrm{mg}$ $\mathrm{L}^{-1}$ ), were used in the same amounts, with larvae of replicates, for the treatment.

EVALUATION OF BACTERICIDAL ACTIVITIES

WITH Staphylococcus aureus AND Escherichia coli

The Minimum Inhibitory Concentrations (MIC) for S. aureus (ATCC 25923) and E. coli (ATCC 25922) were determined using the method of broth macrodilution, as recommended by the National Committee for Clinical Laboratory Standards (NCCLS 2012). Mueller-Hinton broth supplemented with divalent cations calcium (100 $\mathrm{mg} \mathrm{mL} \mathrm{m}^{-1}$ ) and magnesium (50 $\mathrm{mg} \mathrm{mL}^{-1}$ ) was used for this purpose. The bacterial isolates were transferred to nutrient agar and incubated at $37^{\circ} \mathrm{C}$ for 24 hours. The density of the bacterial suspension was adjusted to approximately $108 \mathrm{CFU} \mathrm{mL}^{-1}$ as on
0.5 McFarland scale. This suspension was diluted $1: 100$ with sterile $0.85 \%$ saline and subsequently an aliquot of $20 \mathrm{uL}$ was inoculated into each well (104 CFU/well). Serial dilutions were made and concentrations of the metal complexes were added to the wells. The growth inhibition was analyzed after an incubation period of 24 hours at $37^{\circ} \mathrm{C}$, by observing the amino acid solutions and tetracycline antibiotic solution separately.

\section{STATISTICAL ANALYSIS}

Mortality data for Ae. aegypti were used to estimate the lethal concentration 50\% $\left(\mathrm{LC}_{50}\right)$ and $99 \%\left(\mathrm{LC}_{99}\right)$ for the larval population. The calculation of LCs was performed using the Probit analysis (StatPlus Software 2009). LCs were expressed in milligrams per liter $\left(\mathrm{mg} \mathrm{L}^{-1}\right)$. Estimates of variation of $\mathrm{LC}_{50}$ and $\mathrm{LC}_{99}$ between the complexes were compared by analysis of variance (Kruskal-Wallis $\mathrm{H}$ ) and Mann-Whitney tests. In the analysis of variance, the results of bioassays tested the null hypothesis, that the estimated $\mathrm{LC}_{50}$ and $\mathrm{LC}_{99}$ of each complex were equal, against the alternative hypothesis that at least one of the means for each parameter was different, establishing the significance level of $5 \%$.

\section{RESULTS}

SYNTHESIS AND CHARACTERIZATION

OF L-glutamate-Cu (II) AND L-aspartate-Cu (II) COMPLEXES

The complexes synthesized were obtained with yields of $70.2 \%$ for L-glutamate-Cu (II) and $80.5 \%$ for L-aspartate- $\mathrm{Cu}$ (II). The purification of the complexes was done by solubilizing them in water, precipitation, washing, and drying with absolute ethanol followed by slow evaporation and/or cooling. The $\mathrm{Cu}$ (II) complexes were recrystallized and the crystals formed were isolated, washed and the stoichiometric estimated by elemental analysis. Thus, for the complexes obtained in crystalline state it was possible to estimate from the elemental 
analysis data that the purity is close to $98 \%$. These results are summarized in Table I, which are in agreement with the general formula: $\mathrm{Cu}(\mathrm{L})_{2} \cdot 2 \mathrm{H}_{2} \mathrm{O}$, where $\mathrm{L}=$ glutamate or aspartate.

The infrared spectrum of the L-aspartate- $\mathrm{Cu}$ (II) and L-glutamate-Cu (II) showed that the most important for the analysis bands in the spectra are carboxylate $\left(\mathrm{COO}^{-}\right)$and amino groups $\left(\mathrm{NH}_{2}\right)$. The spectra showed a significant shift, suggesting a possible role in the coordination of the carboxylate metal-ligand (Baran et al. 2000). The resulting Vas (-COO-) and Vs for L-aspartate-Cu (II) were $1585 / 1667$ and $1407 \mathrm{~cm}^{-1}$, respectively, and for L-glutamate-Cu (II) $1384 / 1400$ and $1588 \mathrm{~cm}^{-1}$, respectively (Figure 1).

Table II shows the displacements of the bands of carboxylate groups (COO-) for the amino acids L-glutamic acid and L-aspartic acids and metal complexes L-glutamate- $\mathrm{Cu}$ (II) and L-aspartate- $\mathrm{Cu}$ (II).

The potentiometric titration allows the analysis of deprotonation of the ligand, formation of the complex, and obtaining the constants. The data allow to predict the behavior of these species in the insect digestive tract, as at certain $\mathrm{pH}$, the coordination between ligand and metal varies in the presence or absence of electrical charge that differs according to the $\mathrm{pH}$ of the medium in which the complexes are present. The $\mathrm{pKa}$ is the $\mathrm{pH}$ at which $50 \%$ of coexisting species are unionized (or ionized by the second time). The analysis of $\mathrm{pKa}$ is important for determining the coordination and distribution of species-coordinating function of $\mathrm{pH}$. The tabulated values of $\mathrm{pKa}$ for aspartic acid are pKa1 $(\alpha-\mathrm{COOH}) 2.01, \mathrm{pKr}(\beta-\mathrm{COOH}) 3.90$ and pKa3 $\left(-\mathrm{NH}_{3}^{+}\right)$9.90, and for glutamic acid are pKa1 $(\alpha-\mathrm{COOH}) 2.10,4.07 \mathrm{pKr}(\gamma-\mathrm{COOH})$ and pKa2 $\left(-\mathrm{NH}_{3}^{+}\right)$9.47. The pKa values determined for L-aspartate- $\mathrm{Cu}$ (II) were $\mathrm{pK} 1(\alpha-\mathrm{COOH}) 3.49$, $\mathrm{pKr}(\beta-\mathrm{COOH}) 3.83$ and $\mathrm{pK} 2\left(\alpha-\mathrm{NH}_{3}^{+}\right) 8.31$, and for L-glutamate-Cu (II) were pK1 $(\alpha-\mathrm{COOH})$ 5.30, $\mathrm{pKr}(\gamma-\mathrm{COOH}) 6.37$, and $\mathrm{pK} 2\left(\alpha-\mathrm{NH}_{3}^{+}\right) 9.76$, respectively.

TABLE I

Theoretical and experimental values from elemental analysis for the L-glutamate-Cu (II) and L-aspartate-Cu (II) complexes.

\begin{tabular}{|c|c|c|c|c|c|c|c|c|c|c|}
\hline Complexes & $\% \mathrm{C}$ & $\% \mathrm{C} *$ & $\% \mathrm{H}$ & $\% \mathrm{H}^{*}$ & $\% \mathrm{~N}$ & $\% \mathbf{N} *$ & $\% \mathrm{O}$ & $\% \mathrm{O}^{*}$ & $\% \mathrm{Cu}$ & $\% \mathrm{Cu}^{*}$ \\
\hline Glutamate & 26.87 & 24.54 & 3.55 & 3.71 & 6.65 & 5.72 & - & 39.24 & - & 25.97 \\
\hline Aspartate & 22.20 & 20.82 & 3.63 & 3.94 & 6.65 & 6.07 & - & 41.61 & - & 27.55 \\
\hline
\end{tabular}

* Theoretical value.

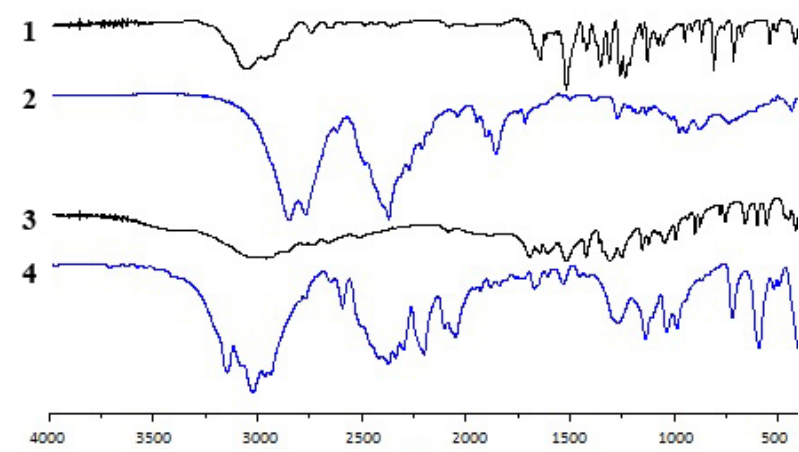

Figure 1 - Infrared spectrum of L-glutamate (1), L-glutamate$\mathrm{Cu}$ (II) (2), L-aspartate (3) and L-aspartate-Cu (II) (4).
TABLE II

Caraboxylate band shifts for L-glutamic acid, L-aspartic acid and metal-amino acid complexes L-glutamate-Cu

(II) and L-aspartate-Cu (II), the displacements were compared as described by Baran et al. 2000.

\begin{tabular}{lcc}
\hline Samples & $\begin{array}{c}\mathbf{V}_{\text {as }}\left(\mathbf{C O O}^{-}\right) \\
\left(\mathbf{c m}^{-1}\right)\end{array}$ & $\begin{array}{c}\mathbf{V}_{\mathbf{s}}\left(\mathbf{C O O}^{-}\right) \\
\left(\mathbf{c m}^{-1}\right)\end{array}$ \\
\hline L-aspartic acid & 1607,1560 & 1421 \\
L-glutamic acid & 1665,1639 & 1436,1419 \\
L-aspartate-Cu (II) & 1667,1585 & 1407 \\
L-glutamate-Cu (II) & 1588 & 1400,1384 \\
\hline
\end{tabular}


The results of the potentiometric titration permit analysis of $\mathrm{pKa}$ and the balance and distribution of species of the complexes L-aspartate-Cu (II) and L-glutamate-Cu (II) as a function of $\mathrm{pH}$ (Figure 2).

Species equilibrium for aspartic and glutamic acids are shown in Figures 3 and 4.

The results of potentiometric titration, visible ultraviolet, and infrared spectroscopy suggest that greater absorption of L-glutamate-Cu (II) occurs in the midgut. The midgut of the insect has a $\mathrm{pH}$ of 10, at which glutamic acid is released with all hydrogen ions and is neutralized and the metalamino acid complex carries no charge, which allows greater permeation in the digestive system through the cell membrane. However, due to system complexity, it is not confirmed that the midgut is the only permeation site for metal-amino acid complex absorption. Figure 5 shows the possible structural arrangement of L-glutamate- $\mathrm{Cu}$ (II) complex at $\mathrm{pH}$ 10.

\section{EVALUATION OF INSECTICIDAL ACTIVITY USING Aedes aegypti LARVAE}

After 24 hours exposure of 3rd instar larvae to the metal complex solution, the values found for the concentration-mortality by L-aspartate-Cu (II) were: $1000 \mathrm{mg} \mathrm{L}^{-1}(100 \%), 500 \mathrm{mg} \mathrm{L}^{-1}$ (95\%); 200 $\mathrm{mg} \mathrm{L}^{-1}(76.66 \%)$, and for L-glutamate-Cu (II) were $600 \mathrm{mg} \mathrm{L}^{-1}$ (83.18\%), $200 \mathrm{mg} \mathrm{L}^{-1}$ (64.54\%), and $50 \mathrm{mg} \mathrm{L}^{-1}$ (47\%). In the control, $100 \%$ mortality occurred only for the insecticide Temephos ${ }^{\circledR} 1$ $\mathrm{mg} \mathrm{L}^{-1}$. These results showed that the mortality curves for the complex are concentrated in the upper $50 \%$,thus indicating that the concentrations used in the bioassays were high and the lethal concentrations (LC) obtained could be reduced (Table III). The concentrations used in toxicity bioassays for each metal-amino acid complex are different. However, for higher concentrations the mortality percentages are similar, which is not true for the other concentrations diluted, possibly due to the solubility of the complexes.

LC for L-glutamate- $\mathrm{Cu}$ (II) are in the confidence interval of L-aspartate-Cu (II), demonstrating that the effect of the insecticide on both metal complexes is similar and that the amino acid ligands have no impact on mortality of Ae. aegypti. Statistical comparisons confirmed bioassays with significant differences $(p<0.05)$ in mortality, suggesting that, despite the low concentrations of L-glutamate- $\mathrm{Cu}$ (II), the insecticidal activity was similar. Statistical analysis showed that it is not possible to state that the L-glutamate- $\mathrm{Cu}$ (II) is superior to L-aspartate$\mathrm{Cu}$ (II), as observed from the analysis of the concentrations of $1000 \mathrm{mg} \mathrm{L}^{-1}$ and $600 \mathrm{mg} \mathrm{L}^{-1}$ after 24-hours exposure. The lethal concentration $\mathrm{LC}_{50}$ and $\mathrm{LC}_{99}$ were obtained through the POLO$\mathrm{PC}$ program, and the $\mathrm{LC}_{50}$ is important as at this concentration, the standard deviation is lower and most of larval population is studied at $\mathrm{LC}_{50}$.

EVALUATION OF BACTERICIDAL ACTIVITY USING Staphylococcus aureus AND Escherichia coli

The MIC for S. aureus ATCC 25923/L-glutamate$\mathrm{Cu}$ (II) was $500 \mathrm{mg} \mathrm{L}^{-1}$ and E. coli/ATCC 25922/L-glutamate-Cu (II) was $2000 \mathrm{mg} \mathrm{L}^{-1}$, and

TABLE III

Lethal Concentrations ( $\mathrm{LC})\left(\mathrm{mg} \mathrm{L}^{-1}\right)$ and confidence interval at $95 \%\left(\mathrm{IC}_{0.05}\right)$ complex of $\mathrm{L}$-aspartate-Cu (II) and L-glutamate-Cu (II) obtained with the mortality of Ae. aegypti.

\begin{tabular}{cccccc}
\hline Complexes & $\mathbf{L C}_{\mathbf{5 0}}\left(\mathbf{I C}_{\mathbf{0 . 0 5}}\right)$ & $\mathbf{L C}_{\mathbf{9 9}}\left(\mathbf{I C}_{\mathbf{0 . 0 5}}\right)$ & $\mathbf{b}_{\mathbf{2} \mathbf{S E} *}$ & $\boldsymbol{\chi}_{\mathbf{2}}$ & $\mathbf{d f * *}$ \\
\hline \multirow{2}{*}{ L-aspartate-Cu (II) } & 108.647 & 809.782 & $0.485 \pm 1.189$ & 4.496 & 22 \\
& $(62.106-144.984)$ & $(568.044-1534.645)$ & & & \\
L-glutamate-Cu (II) & 53.401 & 437.881 & $1.241 \pm 1.543$ & 3.247 & 22 \\
\hline
\end{tabular}

$* \mathrm{~b} \pm \mathrm{SE}$ Coefficient Angle \pm Standard error; ${ }^{* *}$ df Degrees of Freedom. 


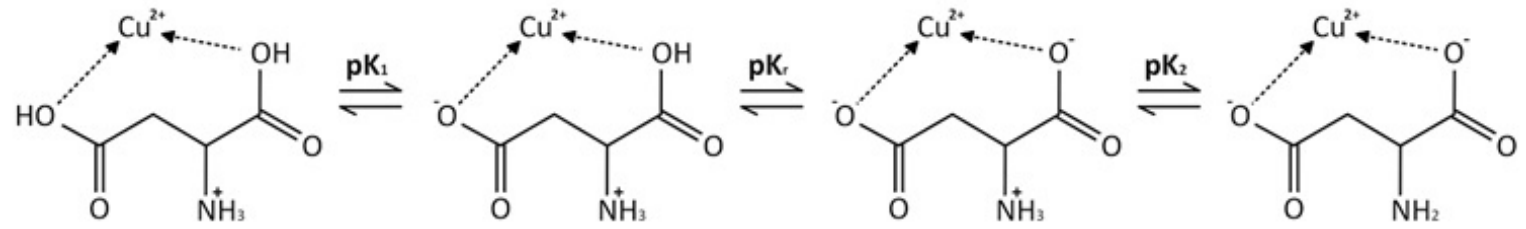

[1]<smiles>[14CH3]OC(=O)CC[C@H](N)C(=O)O[14CH3]</smiles>

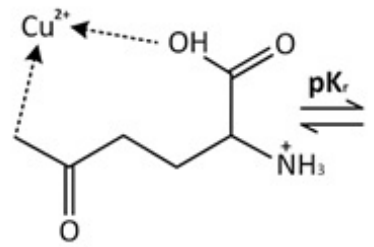<smiles>[14CH3]OC(=O)CC[C@H](N)C(=O)O[14CH3]</smiles>

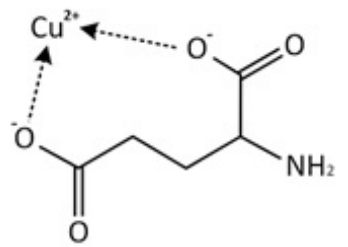

[2]

Figure 2 - Structural forms: L-aspartate-Cu (II) [1] and L-glutamate-Cu (II) [2] in aqueous medium.<smiles>N[C@@H](CC(=O)O)C(=O)O</smiles><smiles>N[C@@H](CC(=O)O)C(=O)[O-]</smiles><smiles>[NH3+]C(CC(=O)[O-])C(=O)[O-]</smiles><smiles>NC(CC(=O)[O-])C(=O)[O-]</smiles>

Figure 3 - L-aspartic acid equilibrium in aqueous medium.<smiles>[NH3+]C(CCC(=O)O)C(=O)O</smiles><smiles>N[C@@H](CCC(=O)O)C(=O)[O-]</smiles><smiles>c1ccccc1</smiles><smiles>NC(CCC(=O)O)C(=O)O</smiles><smiles>NC(CCC(=O)[O-])C(=O)[O-]</smiles>

Figure 4 - L-glutamic acid equilibrium in aqueous medium.

for $S$. aureus ATCC 25923/L-aspartate-Cu (II) was $1000 \mathrm{mg} \mathrm{L}^{-1}$ and E. coli ATCC 25922/L-aspartate$\mathrm{Cu}$ (II) was $2000 \mathrm{mg} \mathrm{L}^{-1}$. The results showed that the metal complexes have different biological activity for Gram-positive (S. aureus) and Gram-negative (E. coli). This aspect could be related to formation of the bacterial cell wall. Gram-positive bacteria have a single wall that consists of peptidoglycan, whereas Gram-negative bacteria have three walls that are composed of polysaccharides, phospholipids and peptidoglycan. These different characteristics in the constitution of the cell wall results in increased resistance to antibiotics in Gram-negative bacteria (Ponnusamy et al. 2008), due to which MIC for E. coli is higher. Bacterial growth was not inhibited in the control.

\section{DISCUSSION}

The potentiometric titration demonstrated the equilibrium and the distribution of the metal 


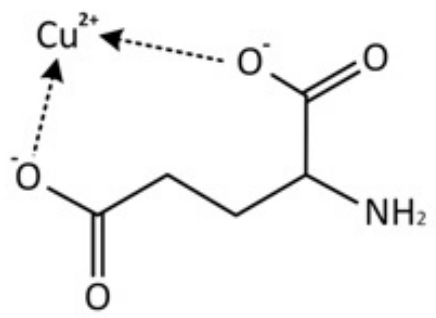

Figure 5 - Complex L-Glutamate$\mathrm{Cu}$ (II) at $\mathrm{pH} 10$ with neutral electric charge.

complex solution in the $\mathrm{pH}$ range of 5 to 10 , being the $\mathrm{pH}$ of absorption and excretion of the metallic complexes in the digestive tract of the insect. The $\mathrm{pH}$ analysis also allows the understanding of metalamino acid coordination, species distribution, toxicity and the electrical charge capacity of the metal to affect the toxicity of the amino acid-Cu (II) complex (Sajadi 2010).

Insects have a complete digestive tract, being: mouth, anterior, middle and posterior intestine (Matta et al. 2016). In this system there is difference of $\mathrm{pH}$ being that at $\mathrm{pH} 10$ occurs the absorption of substances in the middle intestine. Gaban et al. (2015) showed that EDTA-Cu (II), at the concentration of $125 \mathrm{mg} \mathrm{L}^{-1}$, causes brush edge damage and increased cytoplasmic vacuoles in gastric and midgut cells, leading to rupture of the cell junction regions of the stomodeus, possibly due to $\mathrm{pH}$ dependent oxidative stress reactions. At $\mathrm{pH}$ 10 , the ligand is deprotonated to acquire a neutral charge, thereby indicating increased permeation of the complex through the cell membrane.

The toxicity of the metal-amino acid complexes may be related to the lipid solubility of the molecule, since the cell membranes possess a lipid bilayer responsible for the cellular permeation mechanism through the $\mathrm{Na}^{+}$and $\mathrm{K}^{+}$ion channels (Vasconcelos et al. 2007, Ponnusamy et al. 2008). L-glutamate has higher lipid solubility than L-aspartate and this difference in solubility can increase the efficiency of cellular permeation with consequent increase in the transport of the metal complexes, facilitating the induction of oxidative stress reaction in the extracellular environment and the intracellular environment.

The bactericidal effect suggests that the metal complexes can act in a comprehensive (multifunctional) way not only on the target organisms (mosquito larvae), but also on all the bacterial microbiota installed in the mosquito breeding sites. The larvae would come in contact with the metallic complex from the hatching, passing the entire larval stage in that condition. The decrease of the bacterial microbiota would cause food shortages, helping in larval mortality and consequently of the adults that developed in that breeding place.

The results obtained in this study are based on laboratory studies of bioactive substances containing $\mathrm{Cu}$ (II) as active ingredient. Commercial products have not yet been produced and further studies are needed to determine the stability of the metal complexes and their mode of action in the field. Currently, it is known that metal complexes have been used commercially, however, studies are being conducted with respect to metal encapsulation and slow release.

\section{ACKNOWLEDGMENTS}

The authors are grateful to the Dengue-MS Group; Institute of Chemistry and Institute of Biology of UNICAMP(IB/IQ/UNICAMP), Conselho Nacional de Desenvolvimento Científico e Tecnológico (CNPq); Coordenação de Aperfeiçoamento de Pessoal de Nível Superior (CAPES)/Programa Nacional de Cooperação Acadêmica (PROCAD); Fundação de Apoio ao Desenvolvimento do Ensino, Ciência e Tecnologia do Estado de Mato Grosso do Sul (FUNDECT) for supporting our studies in this field of research. 


\section{REFERENCES}

ARRUDA EJ, LEÃO AN, PORTO KRA, OLIVEIRA LCS, ARAKAKI AH, SCHEIDT GN AND SOCCOL CR. 2010. Evaluation of toxic effects with transition metal ions, EDTA, SBTI and acrylic polymers on Aedes aegypti (L., 1762) (Diptera: Culicidae) and Artemia salina (Artemidae). Braz Arch Biol Tech 54: 506-509.

BARAN EJ, WAGNER CC, TORRE MH, KREMER E AND KÖGELER P. 2000. Vibrational spectra of the $\mathrm{Cu}(\mathrm{II})$ complexes of aspartic and glutamic acids. Acta Farm Bonaer 19: 231-234.

BEYENBACH KW. 2012. A dynamic paracellular pathway serves diuresis in mosquito Malpighian tubules. Ann NY Acad Sc 1258: 166-176.

BRUMANO G. 2008. Biotecnologia aplicada ao valor nutricional dos alimentos. Rev Elet Nutri 5: 707-721.

CORBEL V ET AL. 2016. Tracking insecticide resistance in mosquito vectors of arboviruses: The worldwide insecticide resistance network (WIN). PLoS Negl Trop Dis 10: e0005054.

GABAN CRG, ARRUDA EJ, DOURADO DM, SILVA LMGE, VILA NOVA PCC AND CABRINI I. 2015. Morphological changes in the digestive system of Aedes aegypti L. induced by $[\mathrm{Cu}(\mathrm{EDTA})]^{2-c}$ omplex ions. J Mosq Res 5: 1-9.

GOPINATHAN H AND ARUMUGHAM MNJ. 2014. Larvicidal activity of synthesized copper (II) complexes against Culex quinquefasciatus and Anopheles subpictus. J Taib Univ Sci 9: 27-33.

MATTA DH, CIVIDANES FJ, SILVA RJ, SILVA KP AND BATISTA MN. 2016. Ultrastructure of the parties digestive tract of nine species of carabideo (Coleoptera: Carabidae) from Brazil. Ciên Tecn 8: 16-30.

NARDELI JV, ARRUDA EJ, CARVALHO CT, VILA NOVA PCC, CABRINI I AND ARAKAKI AH. 2014. Síntese, caracterização e atividade biológica do acetato de $\mathrm{Cu}$ (II) para larvas de Aedes aegypti e bactérias Escherichia coli,
Staphylococcus aureus, Salmonella typhimurium e Lysteria monocytogenes. Orbital: Elect J Chem 6: 122-129.

NCCLS - NATIONAL COMMITTEE FOR CLINICAL LABORATORY STANDARDS. 2012. Methods for dilution antimicrobial susceptibility tests for bacteria that grow aerobically, Approved standard M07-A9, 29-32.

NECIOSUP E, VERGARA M, PAIRAZAMÁN O, APABLAZA M AND ESPARZA M. 2015. Cobre antimicrobiano contra patógenos intra-hospitalarios en Perú. An Fac Med 76: 9-13.

PONNUSAMY L, XU N, NOJIMA S, WESSON DM, SCHAL C AND APPERSON CS. 2008. Identification of bacteria and bacteria-associated chemical cues that mediate oviposition site preferences by Aedes aegypti. Proc Nat Acad Sc USA 105: 9262-9267.

RAYMS-KELLER A, OLSON KE, MCGAW M, ORAY C, CARLSON JO AND BEATY BJ. 1998. Effect of heavy metals on Aedes aegypti (Diptera:Culicidae) larvae. Ecotoxicol Environ Saf 39: 41-47.

SAJADI SAA. 2010. Metal ion-binding properties of L-glutamic acid and L-aspartic acid, a comparative investigation. Nat Sci 2: 85-90.

SCHOOLEY DA, HORODYSKL FM AND COAST GM. 2012. Hormones controlling homeostasis in insects. In: Gilbert LI (Ed), Insect Endocrinology, New York, USA, p. 367.

STATPLUS SOFTWARE. 2009. Versão 5.8.4.0. AnalystSoft, California, USA.

VASCONCELOS SML, FONSECA MO, MOURA JBF, MANFREDINI V, BENFATO MS AND KUBOTA LT. 2007. Reactive oxygen and nitrogen species, antioxidants and markers of oxidative damage in human blood: main analytical methods for their determination. Quím Nova 30: 1323-1338. 